\title{
Transformation of Industrial By-Products into Composite Photocatalytic Materials
}

\author{
Eleni Katsika1*, Maria Volioti, Vayos G. Karayannis², Angeliki Moutsatsou \\ ${ }^{1}$ Laboratory of Inorganic and Analytical Chemistry, School of Chemical Engineering, National Technical University of Athens \\ (NTUA), 15780 Zografou, Athens, Greece \\ 2 Department of Chemical Engineering, University of Western Macedonia (UOWM), 50100 Kozani, Greece \\ * Corresponding author, e-mail: vkarayan62@gmail.com
}

Received: 05 August 2019, Accepted: 18 October 2019, Published online: 09 December 2019

\begin{abstract}
The transformation of both calcareous and siliceous Greek power station by-products (lignite ashes) into novel composite materials with photocatalytic properties for environmental application was investigated. Particularly, a comparison between the development of coated ceramic substrates and the modification of ash surfaces is attempted. Specifically, a) the sintering process (1000 ${ }^{\circ} \mathrm{C}, 2 \mathrm{~h}$ ) of both fly and bottom ash (either calcareous or siliceous) for their conversion into compacted ceramic substrates coated with $\mathrm{TiO}_{2}$ slurry and then further thermally treated $\left(500^{\circ} \mathrm{C}, 1 \mathrm{~h}\right)$ to acquire $\mathrm{TiO}_{2}$ film consistency onto the ceramic substrate and b) the process of $\mathrm{TiO}_{2}$ precipitation on lignite ash surfaces in acidic solution after neutralization, and estimation of the $\mathrm{TiO}_{2}$ percentage, are compared. The microstructures obtained were examined by XRD and SEM-EDX analysis. Vickers microhardness was also determined for the ceramic microstructures, with satisfactory results (up to $356 \mathrm{HV}$ ). The energy gap measurements of the coatings were found to be between $3.02 \mathrm{eV}$ and $3.17 \mathrm{eV}$, which is located between the energy gap of anatase (3.23eV) and rutile (3.02eV). The coating mass was about $0.059 \mathrm{~g} / \mathrm{cm}^{2}$. The photocatalytic activity under visible and UV irradiation was investigated in aqueous solutions of methylene blue and methyl orange organic dyes, with encouraging results. A main advantage of the processes proposed is the immobilization of $\mathrm{TiO}_{2}$ onto largely available secondary resources, which can lead to production of value-added 'green' photocatalysts for the treatment of industrial effluents in the framework of circular economy.
\end{abstract}

\section{Keywords}

industrial by-product, transformation, photocatalytic material, composite, circular economy

\section{Introduction}

The transformation of industrial by-products, considered as useful secondary raw materials rather than as wastes, into 'green' products can contribute to environmental protection, resources conservation and cost reduction. Nowadays, the environmental legislation strongly encourages manufacturers to utilize industrial by-products, under specific limitations.

Particularly, the processing, upgrading and valorization of Fly Ash (FA) and Bottom Ash (BA), which are produced in massive quantities from coal/lignite combustion for power generation, is currently of increasing importance [1-6]. The recycling and transformation of ashes into value-added materials represents an alternative to disposal and could provide significant economic and environmental benefits. So far, the global average utilization rate has been estimated to be nearly $25 \%$ of FA production [7].
In Greece, approx. 8 million tons of ashes are annually generated from lignite combustion in power stations. $80 \%$ of this amount comes from Northern Greece (Region of Western Macedonia) where the main lignite deposits of the country are located, whereas the rest from Megalopolis (Region of Peloponnese in Southern Greece). The use of FA (mainly in cement industry) still remains to about $20 \%$ of the annual production, while the rest is directly discharged into ponds and landfills. So, utilization of FA must be raised to avoid environmental impacts [8-10].

Research efforts focus on the addition of FA in construction materials including conventional cement-based products as well into clayey mixtures at different combinations and proportions for manufacturing ceramic, glass-ceramic and geopolymeric materials, due to FAs interesting physicochemical properties [11-18]. Moreover, the utilization of 
FA to act as synthetic zeolite for remediation of soils contaminated by heavy metals is reported in other study [19]. Also, FA has been successfully tested as a low-cost adsorbent to remove $\mathrm{Cu}$ and $\mathrm{Cd}$ ions from aqueous solutions [20]. Recent research interest is placed on applications of fly ash for $\mathrm{CO}_{2}$ capture and utilization [21]. Especially, lignite ashes can be considered as attractive secondary resources for use in environmental applications of heterogeneous catalysis due to their aluminosilicate content. This can provide a cost-effective and environment-friendly alternative for the beneficial utilization of ashes [2, 22].

In order to convert by-products such as lignite ashes into photocatalysts, titanium oxide $\left(\mathrm{TiO}_{2}\right)$ can be considered as an appropriate additive, as it is the most common, efficient and usable semiconductor in photocatalytic oxidation, with significant advantages and excellent physicochemical and photocatalytic properties in comparison to the other semiconductors. $\mathrm{TiO}_{2}$ in the crystalline phase of rutile (tetragonal) is the most stable form compared to anatase (tetragonal) and brookite (orthorhombic) phases that are metastable and can be transformed to rutile phase under $\sim 750{ }^{\circ} \mathrm{C}$. Anatase and rutile $\mathrm{TiO}_{2}$ are most often reported as photocatalysts: recent results demonstrated that a mixed form of rutile and anatase $\mathrm{TiO}_{2}$ displayed enhanced photocatalytic ability, since the transfer of electrons from anatase to a lower-energy rutile electron-trapping site in mixed-phase could reduce their combination rate of charge carriers in anatase $\mathrm{TiO}_{2}$ and effectively create catalytic "hot spots" [23, 24].

Furthermore, other inorganic by-products have been studied as substrates for their photocatalytic ability. An example is blast furnace ash as well as the ash of agricultural by-products $[25,26]$. Techniques that have been investigated for depositing $\mathrm{TiO}_{2}$ on the surface of materials of this category are: the co-grinding at high temperatures, the sol-gel method, precipitation, thermal spraying, deposition, pulsed power, and other [27, 28].

The present research focuses on the comparison of two different processes of $\mathrm{TiO}_{2}$ immobilization onto lignite ashes for their transformation into novel photocatalysts:

1. Ceramic substrates are prepared starting from either siliceous or high-calcium ash and, then, their surfaces are activated, by coating them with $\mathrm{TiO}_{2}$ slurry: the microstructures obtained are studied in relation to $\mathrm{TiO}_{2}$ coating, drying and thermal treatment conditions. Apart from eliminating the obstacles encountered with the use of the catalyst in the form of particle dispersions and suspensions (need for solid-liquid separation after treatment, particle aggregation etc.), another significant advantage of the whole process of photocatalyst immobilization is the potential for photocatalytic decomposition of persisting (hardly biodegradable or even non-biodegradable) pollutants. The effect of iron oxides existing in lignite fly ash in small quantities on the photocatalytic activity of $\mathrm{TiO}_{2}$ is also discussed.

2. Siliceous and high-calcium lignite ash (fly and bottom ash) are directly surface activated by $\mathrm{TiO}_{2}$ precipitation onto their surface: the product microstructure is studied according to the parameters of $\mathrm{TiO}_{2}$ precipitation in acidic solution after neutralization and hydrolysis. Moreover, the effect of different mineralogical phases and physicochemical properties of ashes on the rate and form of the resulting $\mathrm{TiO}_{2}$ or even the reaction with components of the ashes is investigated. The research aims to extend the field of ash application for further treatment of liquid wastes such as dye-house, electroplating effluents etc., by studying the effect of surface coating ashes of different particle sizes (as received and $<45 \mu \mathrm{m}$ ) and for $1 \mathrm{~h}$ ageing time. The determination of the ash physicochemical characteristics (specific surface area, specific weight, $\mathrm{pH}$ ) are necessary for the selected technique of transformation/modification.

\section{Materials and methods}

\subsection{Materials}

Fly ash (FAAD) was obtained from the electrostatic precipitators of lignite-fed Agios Dimitrios lignite power plant (Region of Western Macedonia). It is a fine powder highly-calcareous (Class-C according to ASTM C 618). On the other hand, Megalopolis fly ash (FAM) is strongly siliceous: almost half of it consists of $\mathrm{SiO}_{2}$ with lesser amounts of Ca-bearing species also present (barely a Class-C ash).

Bottom ash is also formed during lignite firing in Agios Dimitrios and Megalopolis units (BAAD and BAM respectively), and is removed from the bottom of dry boilers. It is a granular material much coarser than FA.

All types of ash were evaluated in terms of their chemical composition by means of X-ray fluorescence (XRF, X-Lab 2000 EDAX, Siemens D-500), loss on ignition (ASTM D7348), pH (ISO 6588) and free $\mathrm{CaO}$ content (CaOf-ASTM C151). Mineralogical analysis was performed by X-ray Diffraction, while the particle size distribution was determined using Malvern MasterSize-S by applying the wet dispersion method in water. 
The chemical content, the physicochemical properties and the mineralogical composition of the ashes are given in Tables 1 and 2, and Fig. 1 respectively. The main crystalline phases detected in the Agios Dimitrios ashes (FAAD and BAD) are gypsum $\left(\mathrm{CaSO}_{4} \cdot 2 \mathrm{H}_{2} 0\right)$, quartz $\left(\mathrm{SiO}_{2}\right)$, lime $(\mathrm{CaO})$, calcite $\left(\mathrm{CaCO}_{3}\right)$, and a-hematite $\left(\mathrm{Fe}_{2} \mathrm{O}_{3}\right)$. On the other hand, the main mineralogical phases of the Megalopolis ashes (FAM and BAM) are quartz $\left(\mathrm{SiO}_{2}\right)$, silicon oxide $\left(\mathrm{SiO}_{2}\right)$ and iron oxide $\left(\mathrm{Fe}_{2} \mathrm{O}_{3}\right)$.

\subsection{Preparation of coated ceramic substrates}

Disc-shaped compacted specimens (13 mm diameter and $3 \mathrm{~mm}$ width) were formed each time from FAAD and FAM by uniaxially cold pressing in a stainless-steel die using a hydraulic press (Specac, 15011), and then were consolidated employing sintering procedure in a laboratory chamber programmable furnace (Thermoconcept, KL06/13). A temperature lower than the vitrification point of the ashes was selected as a peak sintering temperature $\left(1000{ }^{\circ} \mathrm{C}\right)$, with $2 \mathrm{~h}$ soaking time. Finally, the sintered specimens were gradually cooled to ambient temperature into the furnace. Then the specimen surfaces were coated with $\mathrm{TiO}_{2}$ slurry ( $8 \% \mathrm{TiO}_{2}, 89.9 \%$ water and $2.1 \%$ disruptive factor), and subsequently were exposed at $500{ }^{\circ} \mathrm{C}$ for $1 \mathrm{~h}$ to acquire $\mathrm{TiO}_{2}$ consistency on the ceramic substrate.

The obtained microstructures were thoroughly examined by XRD and SEM-EDAX (Jeol, JSM-6400). Also, the difference of the ceramic substrate microstructures after the second heating treatment was examined for the surface consistency. The shrinkage of the samples was calculated as the volume change (\%) upon sintering. The apparent density was determined according to the Archimedes principle using a specific apparatus (Shimadzu, SMK401AUW220V). Vickers microhardness was measured with a load of $50 \mathrm{~g}$ and a dwell time of $15 \mathrm{~s}$ (Wilson Instruments, Mode 402MVD, Knoop Vickers Tester). In order to enable reliable comparisons, mean microhardness values over five valid indentations per specimen were calculated. Moreover, the average surface roughness of the coated substrates was determined (Bruker, Nano Surfaces Division, Countour GT, Vision 64 Software).

\subsection{Preparation of coated lignite ash powders}

For the direct surface coating of lignite ashes with $\mathrm{TiO}_{2}$, the technique of hydrolysis and simple precipitation was used. This choice was established taking into consideration the physicochemical characteristics of the ashes and the low cost of the process in relation with the price
Table 1 Chemical content of FAAD, BAAD, FAM and BAM

\begin{tabular}{lrrrr}
\hline$(\%)$ & FAAD & BAAD & FAM & BAM \\
\hline $\mathrm{SiO}_{2}$ & 30.16 & 48.63 & 49.54 & 50.23 \\
$\mathrm{Al}_{2} \mathrm{O}_{3}$ & 14.93 & 21.62 & 19.25 & 20.40 \\
$\mathrm{Fe}_{2} \mathrm{O}_{3}$ & 5.10 & 7.29 & 8.44 & 9.35 \\
$\mathrm{CaO}$ & 34.99 & 6.83 & 11.82 & 7.90 \\
$\mathrm{MgO}$ & 2.69 & 2.75 & 2.27 & 2.30 \\
$\mathrm{SO}_{3}$ & 6.28 & 2.78 & 3.91 & 1.89 \\
$\mathrm{~N}_{\mathrm{a} 2} \mathrm{O}$ & 1.01 & 0.89 & 0.53 & 0.45 \\
$\mathrm{~K}_{2} \mathrm{O}$ & 0.40 & 2.97 & 1.81 & 1.98 \\
$\mathrm{LOI}$ & 3.95 & 5.34 & 2.10 & 5.78 \\
& $* \mathrm{CaO}_{\mathrm{f}}:$ & & $* \mathrm{CaO}:$ & \\
& $10.87 \%$ & & $5.95 \%$ & \\
\hline
\end{tabular}

Table 2 Physicochemical properties of the ashes

\begin{tabular}{lrccc}
\hline & \multicolumn{3}{c}{ Particle size distribution } \\
& $\mathrm{pH}$ & $\mathrm{D}(\mathrm{v}, 0.5)$ & $\mathrm{D}(\mathrm{v}, 0.9)$ & $\begin{array}{c}\text { Specific Weight } \\
\left(\mathrm{g} / \mathrm{cm}^{3}\right)\end{array}$ \\
\hline FAAD & 12.5 & 30.92 & 98.28 & 2.67 \\
BAAD & 8.5 & 85.93 & 199.08 & 2.74 \\
FAM & 11.8 & 98.92 & 199.87 & 2.62 \\
BAM & 8.9 & 97.92 & 208.14 & 2.73 \\
\hline
\end{tabular}

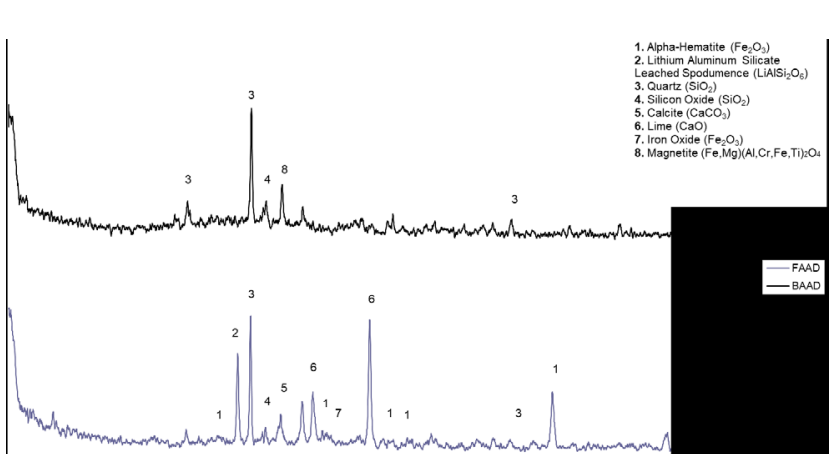

(a)
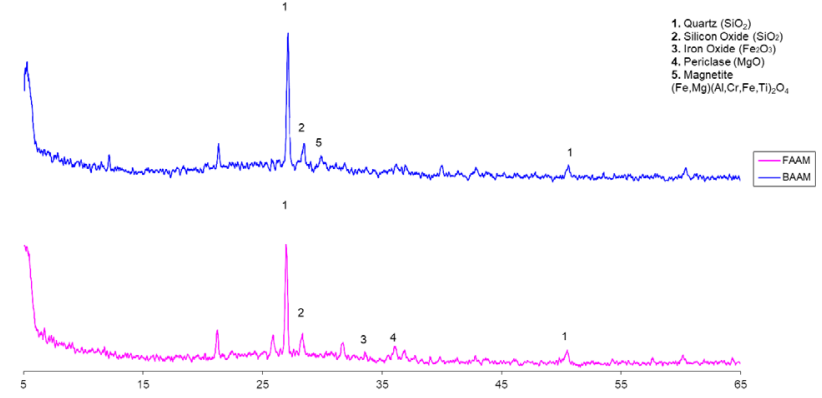

(b)

Fig. 1 Mineralogical composition of the (a) FAAB and BAAD and (b) FAM and BAM ashes.

of the raw material. Acidic solution of $\mathrm{TiCl}_{4}\left(\mathrm{TiCl}_{4} / \mathrm{HCl}\right.$ 1:2.5 moles) was prepared, in order to avoid the formation of orthotitanate acid. Then $18 \mathrm{~g}$ of lignite ash (particle size as-received and after grinding to $<45 \mu \mathrm{m}$ ) was 
added under stirring in the solution. Moreover, for the

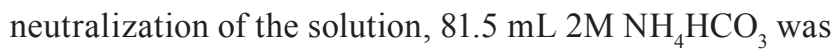
added. Then the final solution was subjected to $1 \mathrm{~h}$ ageing time. The product was filtered, dried for $24 \mathrm{~h}$ and sintered at $500{ }^{\circ} \mathrm{C}$ for $2 \mathrm{~h}$. Its microstructure was examined by X-ray diffraction (Siemens D-500) and by Scanning Electron Microscopy (FEI Quanta 200 coupled with an EDAX detector).

\subsection{Photocatalytic activity}

The photocatalytic activity of the composite materials produced was evaluated in the decolorization of two organic dyes (potential pollutants) as a function of time, under visible (daylight) or UV (UV-A) irradiation. The dye used in the experiments under visible irradiation was Methylene Blue (MB), a cationic dye with molecular formula $\mathrm{C}_{16} \mathrm{H}_{18} \mathrm{ClN}_{3} \mathrm{~S}$, while the dye used under UV irradiation was Methyl Orange (MO), an anionic dye with molecular formula $\mathrm{C}_{14} \mathrm{H}_{14} \mathrm{~N}_{3} \mathrm{NaO}_{3} \mathrm{~S}$. The selection of $\mathrm{MB}$ and $\mathrm{MO}$ was made because they are commonly used as standard pollutant compounds in many studies, and their absorption is easy to detect through spectrophotometry measurements. Indeed, organic dyes are important and common effluents of textile industry [29, 30].

Synthetic aqueous solutions of $\mathrm{MB}$ and $\mathrm{MO}$ with initial concentrations of $0.4 \times 10^{-5} \mathrm{M}$ and $1.7 \times 10^{-5} \mathrm{M}$ respectively were prepared, by dissolving dye powder (Fluka and Merck respectively) in distilled water. The solutions were saturated in oxygen by bubbling $\mathrm{O}_{2}$ in the solution for $1.5 \mathrm{~h}$ prior to use. The photocatalytic process was carried out in round-bottom photocatalytic Pyrex glass cells that are transparent to wavelengths above $320 \mathrm{~nm}$. The activated disc-shaped substrates were cut in surface areas of about $1 \mathrm{~cm}^{2}$ and inserted in the photocatalytic cell with $5 \mathrm{ml}$ of the dye solution. In the case of the e lignite ashes powders coated with $\mathrm{TiO}_{2}$, quantity of $5 \mathrm{mg}$ was inserted in the cell along with $5 \mathrm{ml}$ of the dye solution.

The laboratory system used for the irradiation of the cells containing the samples was equipped with four parallel OSRAM L15W/865 LUMILUX Cool Daylight tubes for the experiments under visible light. For UV irradiation, two experiment series were carried out, using either SYLVANIA blacklight 368 F15W/T8/BL368 tubes with maximum emission at $368 \mathrm{~nm}$, either SYLVANIA blacklight blue F15W/BLB-T8 tubes with maximum emission at $350 \mathrm{~nm}$. All photocatalytic experiments were performed under continuous magnetic stirring, while $\mathrm{pH}$ and temperature values of the solutions were maintained constant.
The decomposition of the dye pollutants as a function of time and the decolorization rate were spectrophotometrically determined (UV-VIS Spectrophotometer HITACHI U-2001) by recording the absorption spectra of samples taken out at specific time intervals and measuring the change in intensity of the characteristic peak at the maximum absorption wavelength of the dyes $\left(\lambda_{\text {max,MB }}=\right.$ $\left.664.0 \mathrm{~nm}, \lambda_{\max , \mathrm{MO}}=463.0 \mathrm{~nm}\right)$. Then, the dye decomposition efficiency was determined using the following equation:

$\operatorname{Efficiency}(\%)=\frac{\left(C_{0}-C\right) 100}{C_{0}}$,

where: $C_{0}$ is the initial concentration of dye solution and $C$ is the final concentration after illumination by visible or UV light.

\section{Results and discussion}

XRD spectra of the coating of the ceramic substrates under different thermal treatment conditions are presented in Fig. 2. It can be seen that the main mineral phases of all coated surfaces are anatase and rutile.

The mineralogical analysis of the ceramic substrates obtained either from FAAD or FAM fly ash is shown in Fig. 3 (a) and 3 (b) respectively. For the ceramic substrates made of FAAD, the main phases are anhydrite and quartz. In the non-sintered specimen (Fig. 3 (a), A), the intensity of the peak associated with lime $(\mathrm{CaO})$ predominates. The ash specimens sintered up to $1000{ }^{\circ} \mathrm{C}$ (Fig. 3 (a), B) as well as those further thermally treated after coating (Fig. 3a, C) exhibit different mineralogical compositions, and after the thermal treatment, gehlenite, anhydrite and quartz are the main phases. For FAM non-sintered specimens, quartz $\left(\mathrm{SiO}_{2}\right)$ is the predominant phase (Fig. 3 (b), A), while quartz, cyanite and gehlenite are detected after sintering the specimens up to $1000{ }^{\circ} \mathrm{C}$ (Fig 3 (b), B). The same phases appear in the substrates further thermally treated after coating (Fig. 3 (b), C). Therefore, it can be concluded that the mineralogical phases

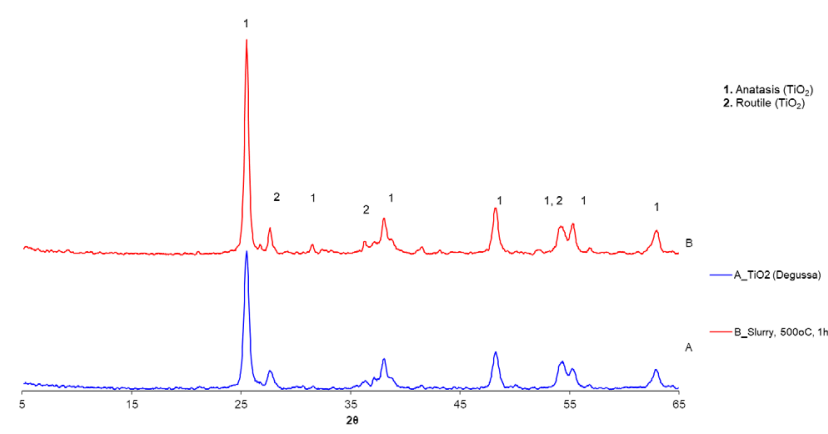

Fig. 2 XRD spectra of the coating of the ceramic substrates: (A) $\mathrm{TiO}_{2}$ (Degussa) and (B) sintered at $500{ }^{\circ} \mathrm{C}$ for $1 \mathrm{~h}$. 


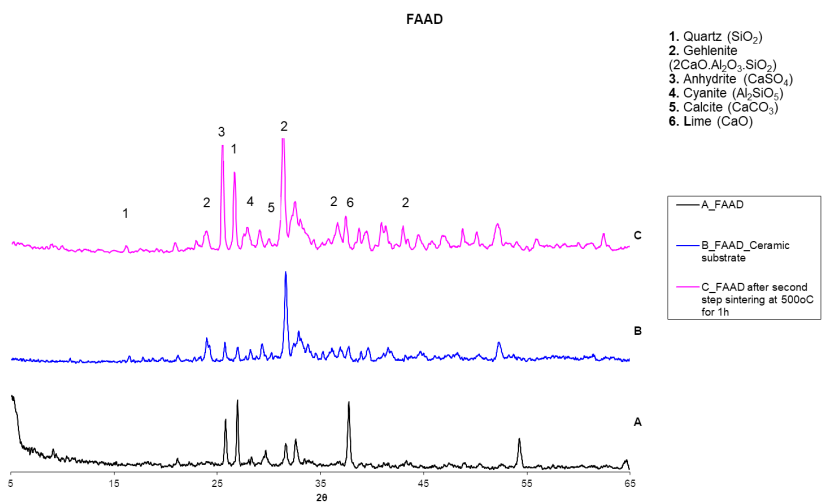

(a)

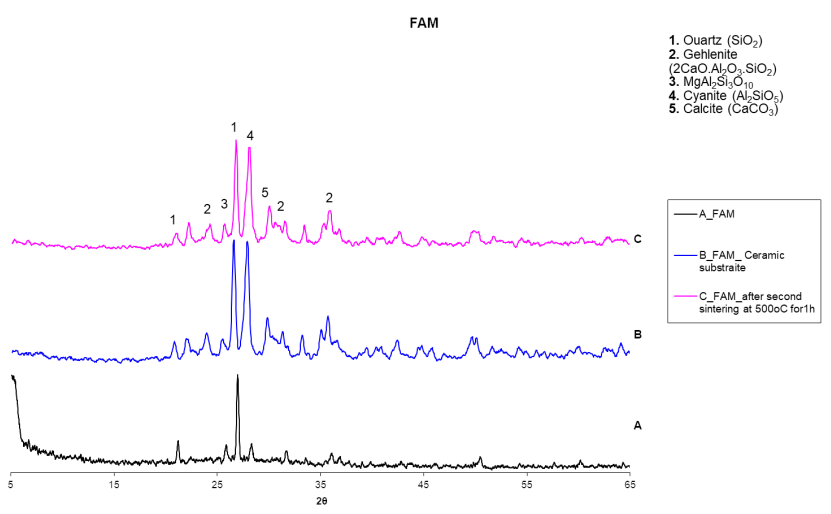

(b)

Fig. 3 XRD spectra of the ceramic substrates (a) FAAD and (b) FAM:(A) non-sintered, (B) after sintering at $1000^{\circ} \mathrm{C}$ and (C) after further thermal treatment of the coated substrates at $500{ }^{\circ} \mathrm{C}$ for $1 \mathrm{~h}$.

detected after further heating of the coated substrates were already generated during the main sintering process and no further mineralogical change is recorded.

SEM micrographs of the ceramic substrate surface coating after thermal treatment at $500{ }^{\circ} \mathrm{C}$ for $1 \mathrm{~h}$ is provided in Fig. 4.

Surface coating cracks are clearly seen on the ceramic substrates due to the removal of water and degradation of the organic compounds of the slurry during heating. The surface roughness of the $\mathrm{TiO}_{2}$-coated substrates after their thermal treatment at $500{ }^{\circ} \mathrm{C}$ was found to be $15.8 \mathrm{Sa}(\mu \mathrm{m})$ for FAAD and 5.81 Sa $[\mu \mathrm{m}]$ for FAM. The apparent density of the sintered substrates lies in the range of $1.17-1.78 \mathrm{~g} /$ $\mathrm{cm}^{3}$. The Vickers microhardness for the non-sintered specimens is $230 \mathrm{HV}$ and raises up to $469 \mathrm{HV}$ after sintering.

On the other hand, the surface of lignite ashes is coated with $\mathrm{TiO}_{2}$ of an amount of 20 to $56 \%$, as it was deduced by weight measurements conducted. The results are presented in Table 3. It can be noted that bottom ashes seem to have greater coating rates, which can be mainly attributed to their higher porosity.

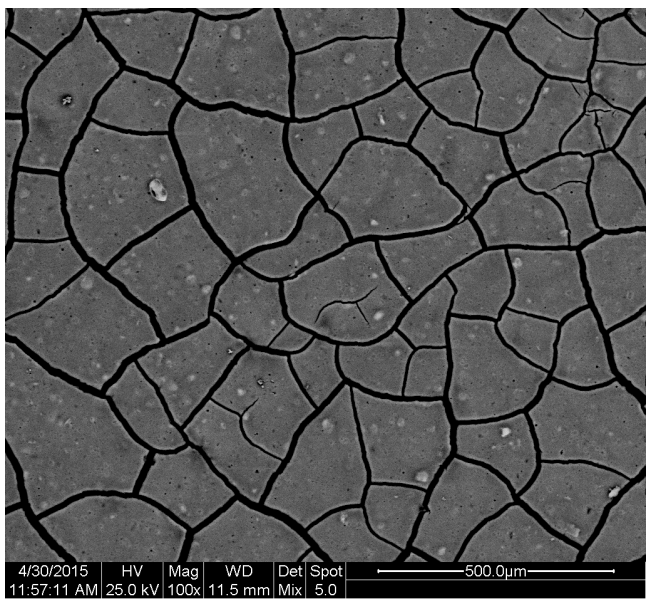

Fig. 4 SEM micrographs of the surface coating of ceramic substrates thermally treated for $1 \mathrm{~h}$ at $500^{\circ} \mathrm{C}$.

Table $3 \% \mathrm{TiO}_{2}$ precipitated on ash surfaces

\begin{tabular}{ccccc}
\hline & FAAD & BAAD & FAM & BAM \\
\hline As received & $20.13 \%$ & $55.97 \%$ & $31.08 \%$ & $40.94 \%$ \\
\hline
\end{tabular}

In Fig. 5, XRD spectra of non-sintered and sintered $\left(500{ }^{\circ} \mathrm{C}, 2 \mathrm{~h}\right.$ ) coated FAAD (particle size as received, ageing time $1 \mathrm{~h}$ ) and BAAD (as received - ageing time $1 \mathrm{~h}$ ) high-Ca ashes are shown.

It can be observed (Fig. 5) that the crystalline phase of calcite is decomposed upon heating and the phases that obviously predominate in the sintered materials are quartz $\left(\mathrm{SiO}_{2}\right)$, calcium titanium oxides $\left(\mathrm{CaTiO}_{3}, \mathrm{Ca}_{2} \mathrm{Ti}_{5} \mathrm{O}_{12}\right)$, as well as anatase and rutile $\left(\mathrm{TiO}_{2}\right)$.

Experiments performed with the siliceous ashes at the received particle size and $1 \mathrm{~h}$ ageing time of the precipitate (Fig. 6, XRD spectra of $500{ }^{\circ} \mathrm{C}, 2 \mathrm{~h}$ sintered (a) coated FAM, (b) BAM) revealed a decomposition of calcium titanium oxide $\left(\mathrm{CaTiO}_{3}\right)$ with temperature increase and main crystalline phases present are quartz $\left(\mathrm{SiO}_{2}\right)$, anatase and rutile $\left(\mathrm{TiO}_{2}\right)$. Quartz $\left(\mathrm{SiO}_{2}\right)$ has a dominating role due to the strongly siliceous character of the Megalopolis ashes. No differences in the mineralogical investigation in relation to the chosen parameters were observed.

For the quantitative determination of the $\mathrm{TiO}_{2}$ phases deposited onto the ash surfaces, X-ray diffraction patterns (XRD) of the calcinated powders were obtained in the diffraction angle range $2 \Theta=20-80 \mathrm{O}$ using $\mathrm{Cu} \mathrm{K} \alpha$ radiation. Then, anatase/rutile percentages were calculated from the resulting diffracrograms using the Spurr-Myers equation [31]:

$$
\%_{\text {Rutile }}=\frac{1}{1+0.8\left[\frac{I_{A}(101)}{I_{R}(110)}\right]} \text {. }
$$




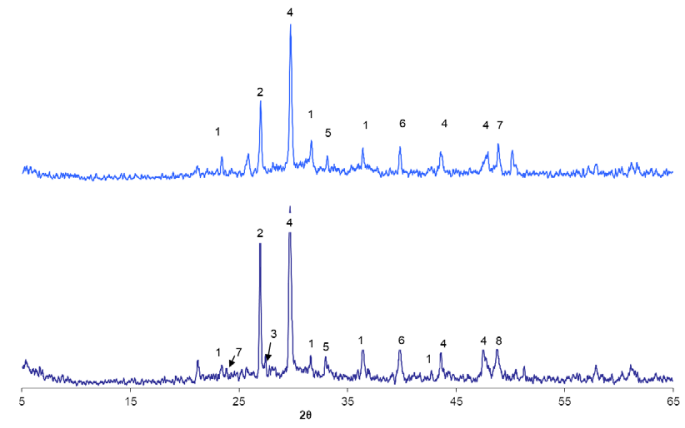

(a)

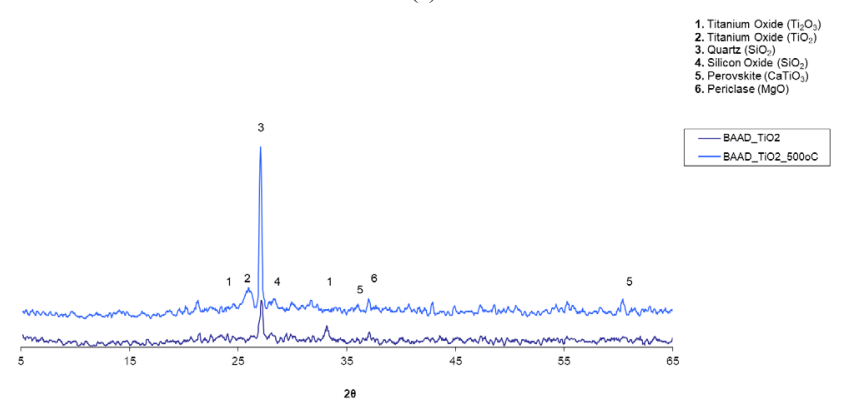

(b)

Fig. 5 XRD spectra of non-sintered and sintered $\left(500{ }^{\circ} \mathrm{C}-2 \mathrm{~h}\right)$ (a) coated FAAD $($ b) coated BAAD

where $I_{\mathrm{A}}$ is the intensity of (101) peak of anatase and $I_{R}$ is the intensity of (110) peak of rutile structure.

In all $\mathrm{TiO}_{2}$-coated ashes tested, the weight fraction of each crystal phase was calculated from the peak areas of the anatase (AA) and rutile (AR) peaks at $25.3^{\circ}(2 \Theta)(101)$ and $27.5^{\circ}(110)(2 \Theta)$ respectively. Furthermore, the rutile percentages are represented in Table 4.

Regarding the morphology of the specimens, a red tint colouring specifically for those prepared starting from Megalopolis ashes appeared, because of the transformation of $\mathrm{Fe}$ compounds to $\mathrm{Fe}_{2} \mathrm{O}_{3}$, as it was indicated by XRD. SEM micrographs (Fig. 7) reveal effectively densified microstructures, and differences due to the mineralogical phases and the granulometry of the ashes can be seen. The surface of the BAAD and BAM ashes coated with $\mathrm{TiO}_{2}$ appears slightly more porous compared to that of the coated FAAD and FAM ones, which should be due to carbon burnout during sintering and also the existence of coarser particles. It should be mentioned that fly ashes contain not only dense solid but also hollow particles (cenospheres) that can be filled with $\mathrm{TiO}_{2}$ during the process (e.g. Fig. 7 (b))EDX analysis, in fact, verified $\mathrm{TiO}_{2}$ presence on cenospheres. Since cenospheres are consisted of glassy $\mathrm{SiO}_{2}$, a better behavior of $\mathrm{Ti}$ in the absence of $\mathrm{Ca}$ may be indicated. It is also worthnoty that porosity may be desirable to attain weight reduction of the final products as

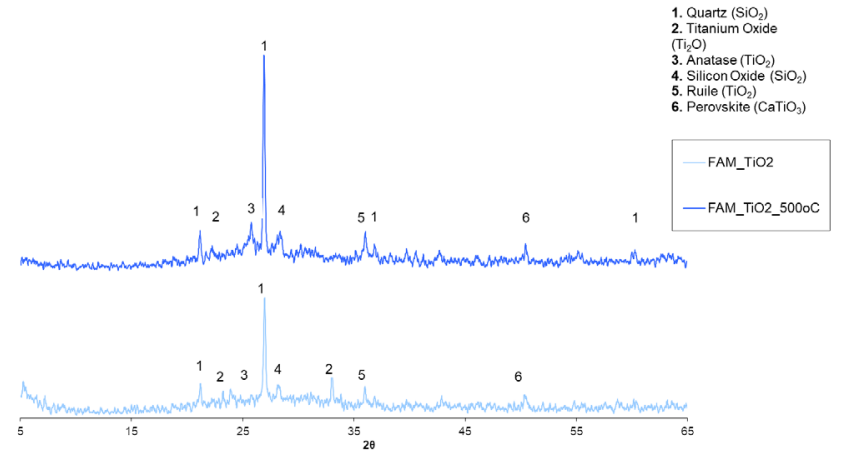

(a)

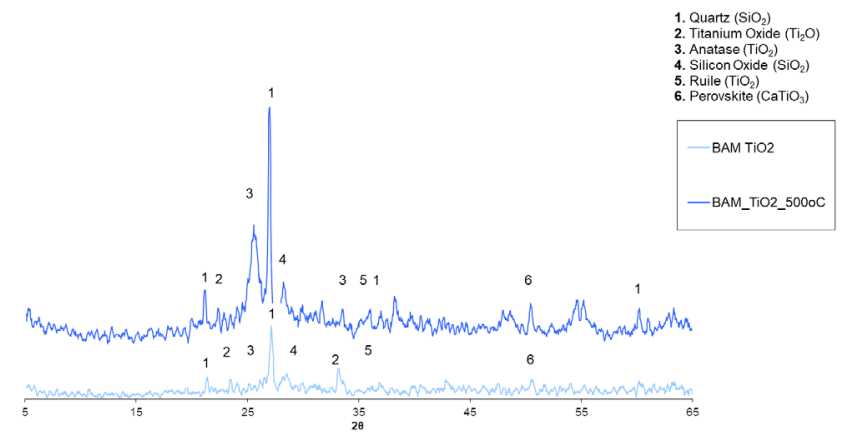

(b)

Fig. 6 XRD spectra of non-sintered and sintered $\left(500{ }^{\circ} \mathrm{C}-2 \mathrm{~h}\right)$ of (a) coated FAM (b) coated BAM

Table 4 Rutile percentages calculated by Spurr-Myers equation

\begin{tabular}{lc}
\hline & As Received \\
\hline FAAD (coated with $\mathrm{TiO}_{2}$ ) sintered in $500{ }^{\circ} \mathrm{C}$ & 63 \\
BAAD (coated with $\mathrm{TiO}_{2}$ ) sintered in $500{ }^{\circ} \mathrm{C}$ & 55 \\
FAM (coated with $\mathrm{TiO}_{2}$ ) sintered in $500{ }^{\circ} \mathrm{C}$ & 44 \\
BAM (coated with $\mathrm{TiO}_{2}$ ) sintered in $500{ }^{\circ} \mathrm{C}$ & 43 \\
\hline
\end{tabular}

well as for specific applications such as the treatment of a liquid wastes through a bed reactor filled with ashes.

The photocatalytic activity of $\mathrm{TiO}_{2}$-coated ceramic substrates made of lignite ashes and thermally treated at $500{ }^{\circ} \mathrm{C}$ is illustrated in Fig. 8, which shows the methylene blue (MB) and methyl orange (MO) dye removal in aqueous solution as a function of irradiation time, under visible (cool daylight) and two types of UV-A light (blacklight and blacklight blue).

Concerning the experiments under visible light, a very intense decolorization of MB can be observed, while the highest activity is exhibited by the coated ceramic substrates made from FAAD, followed by those from bottom ash of the same power station.

Dye decomposition may partially be attributed to dye adsorption onto the porous and cracked coating on the ceramic substrate, taking into consideration the 


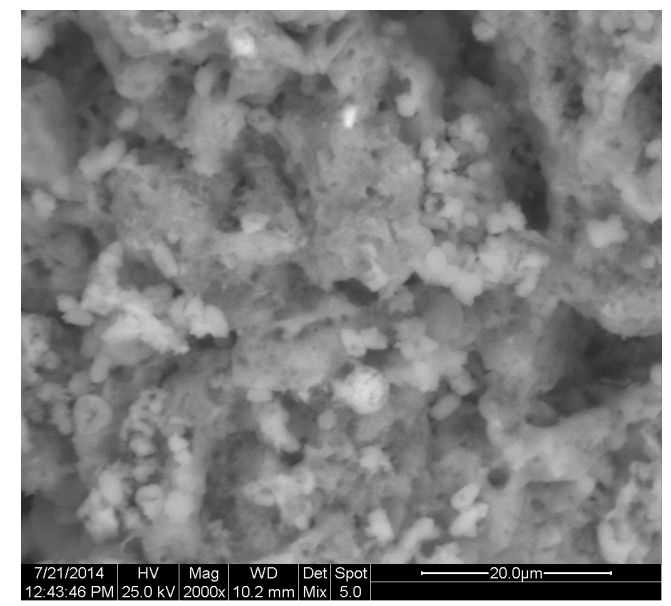

(a)

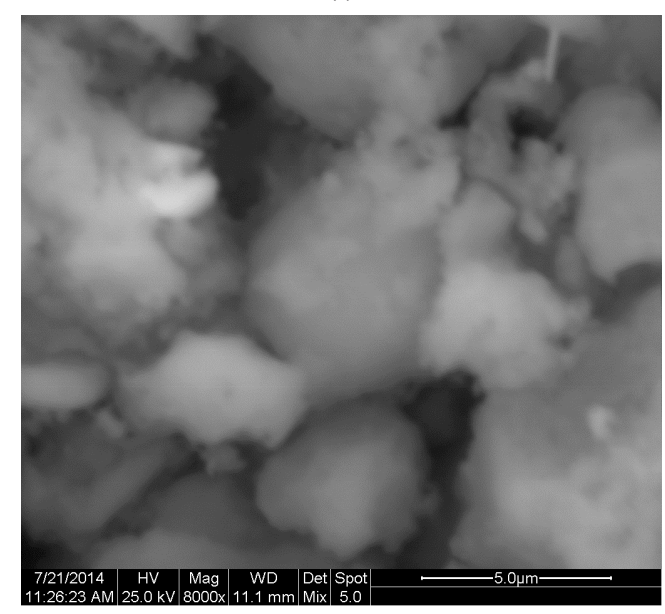

(c)

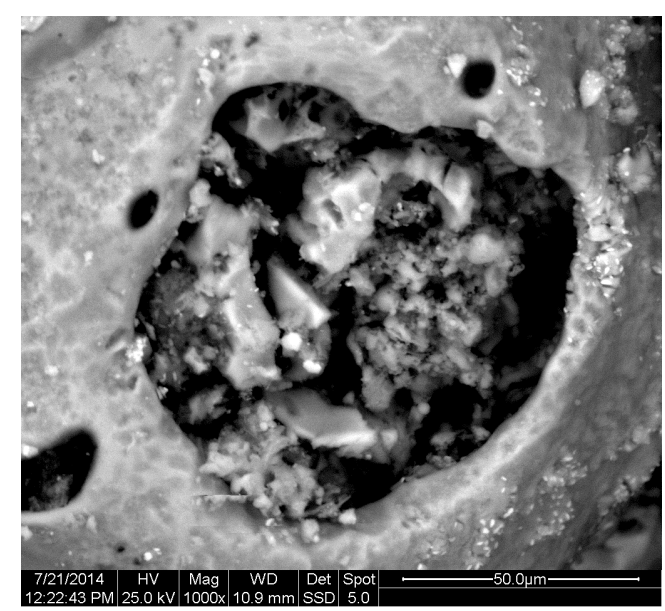

(b)

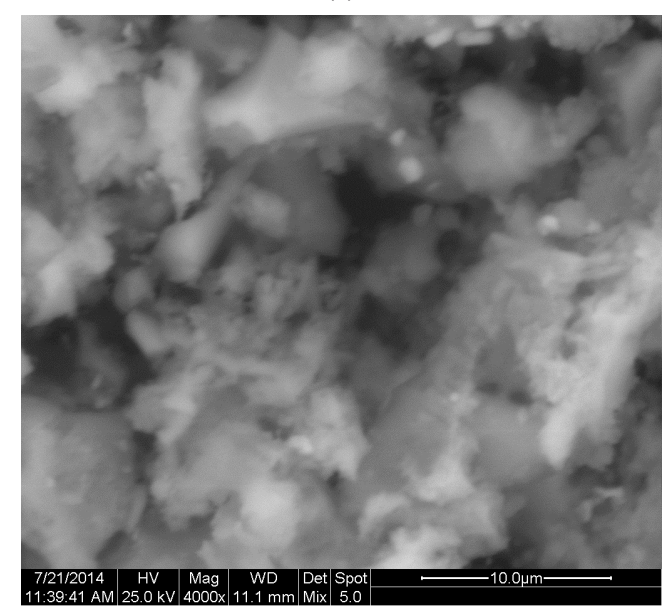

(d)

Fig. $7 \mathrm{SEM}$ micrographs of sintered $\left(500^{\circ} \mathrm{C}, 2 \mathrm{~h}\right.$ ) coated with $\mathrm{TiO}_{2}$ (a) FAAD, (b) BAAD, (c) FAM, and (d) BAM.

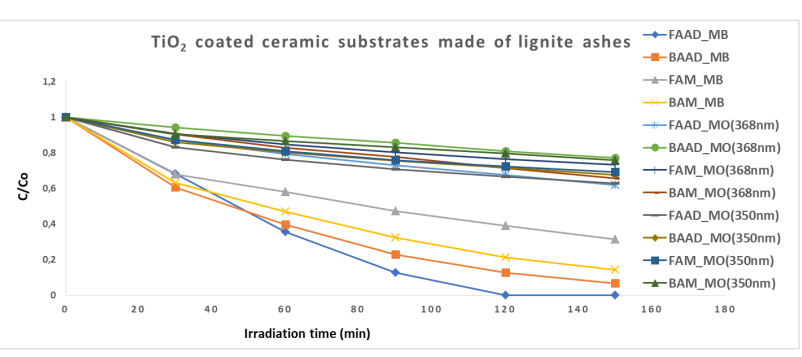

Fig. 8 Dye removal by the $\mathrm{TiO}_{2}$-coated ceramic substrates made of lignite ashes, under visible and $\mathrm{UV}$ light, as a function of irradiation time.

aforementioned surface roughness results. It can, therefore, be assumed that during the experiments a combined mechanism takes place, which includes both adsorption and especially photodegradation phenomena.

On the other side, the removal of MO by the activated composite materials under the two types of UV-A irradiation, which is depicted in the same graph, is less pronounced than in the case of MB experiments. This finding should be correlated to the fact that the dye removal efficiency depends on the pollutant itself, the irradiation type and other system parameters. Especially, high solution $\mathrm{pH}$ values encountered due to the alkaline nature of the ashes favor the adsorption of the cationic MB dye onto the substrate surface, whereas the removal of the anionic MO dye is negatively affected.

In Fig. 9, the dye removal results using the activated ( $\mathrm{TiO}_{2}$-coated) lignite ashes are graphically presented. Similarly to the coated ceramic substrates, the application of the activated lignite ash powders to the removal of $\mathrm{MB}$ under visible light leads to higher activity and thus higher dye decomposition compared to that of $\mathrm{MO}$ where no significant decolorization of the aqueous dye solution is demonstrated. Indeed, the highest MB removal rates are achieved for the two types of bottom ashes (BAAD and BAM), which is indicative of a better synergy of these two secondary materials examined, with $\mathrm{TiO}_{2}$.

With regard to MO removal from the modified powdery lignite ashes, the obtained results are similar for the 


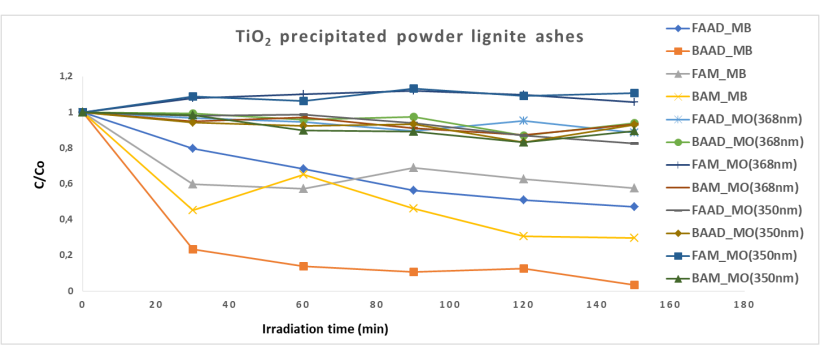

Fig. 9 Dye removal by lignite ash powders modified with $\mathrm{TiO}_{2}$ precipitation, under visible and $\mathrm{UV}$ light, as a function of irradiation time.

two types of UV-A irradiation but of fairly low efficiency. However, an interesting finding is that in all cases of the samples prepared from bottom ashes, the maximum dye removal was obtained at 120 min of irradiation and not at $150 \mathrm{~min}$ that as would be expected. This may be attributed to a possible desorption that takes place after a specific time.

The effectiveness of all composite materials produced for potential environmental applications, in terms of $\%$ pollutant (dye) removal efficiency, is summarized in Fig. 10, which provides an overall comparison. It is obvious from this graph that in all three dye/irradiation combinations examined, greater dye removal efficiency is generally demonstrated in the form of $\mathrm{TiO}_{2}$-coated ceramic substrates rather than in the form of the activated lignite ash powders. The improved performance of the coated ceramic substrates may be explained by a higher adsorption capacity of the substrates and especially an enhanced photocatalytic activity of their $\mathrm{TiO}_{2}$ film coating, promoting the dye decomposition [32].

\section{References}

[1] Feigl, V., Gruiz, K., Anton, A. "Remediation of metal ore mine waste using combined chemical- and phytostabilisation", Periodica Polytechnica Chemical Engineering, 54(2), pp. 71-80, 2010.

https://doi.org/10.3311/pp.ch.2010-2.03

[2] Baklavaridis, A. N., Samaras, P. E., Karayannis, V. G. "Recent progress in the advanced oxidation of wastewaters using recycled fly ashes as alternative catalytic agents", Desalination and Water Treatment, 133, pp. 292-306, 2018.

https://doi.org/10.5004/dwt.2018.23084

[3] Karamberi, A., Orkopoulos, K., Moutsatsou, A. "Synthesis of glass-ceramics using glass cullet and vitrified industrial by-products", Journal of the European Ceramic Society, 27(2-3), pp. 629636, 2007.

https://doi.org/10.1016/j.jeurceramsoc.2006.04.126

[4] Nicoara, A. I., Badanoiu, A., Balanoiu, M., Mathias, A., Voicu, G. "Alkali Activated Mortars with Intumescent Properties", Revista de Chimie, 70(2), pp. 431-437, 2019.

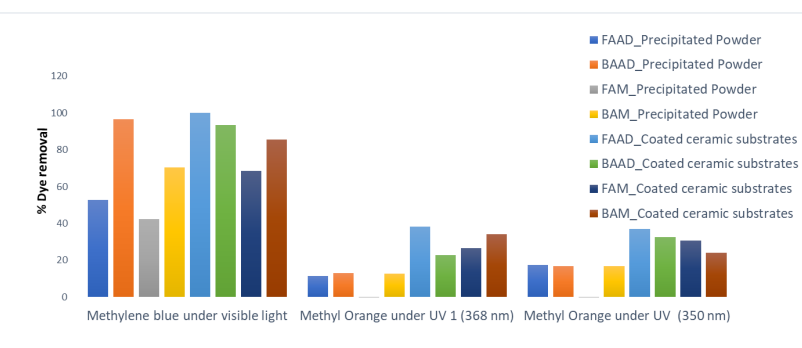

Fig. 10 Comparative \% dye removal values for all the activated samples and experimental conditions

\section{Conclusions}

Both calcareous and siliceous Greek lignite ashes, largely available power station by-products, were successfully transformed into composite materials with photocatalytic activity.

A comparison between a) ceramic substrates developed from the ashes and coated with $\mathrm{TiO}_{2}$ film deposition and b) fly ash powders, surface modified with precipitation of $\mathrm{TiO}_{2}$, reveals a greater pollutant (organic dye) removal photocatalytic efficiency for the $\mathrm{TiO}_{2}$-coated ceramic substrates rather than for the activated lignite ash powders. This finding should be attributed to a higher dye adsorption capacity of the substrates mainly combined with an increased photocatalytic activity of the $\mathrm{TiO}_{2}$ film coating.

Concluding, the results of the current research appear to be encouraging for further development of alternative value-added photocatalytic materials starting from industrial secondary resources, for their valorization in wastewater treatment in the context of circular economy.

[5] Savvilotidou, V., Kritikaki, A., Stratakis, A., Komnitsas, K., Gidarakos, E. "Energy efficient production of glass-ceramics using photovoltaic $(\mathrm{P} / \mathrm{V})$ glass and lignite fly ash", Waste Management, 90, pp. 46-58, 2019.

https://doi.org/10.1016/j.wasman.2019.04.022

[6] Tsimas, S., Moutsatsou-Tsima, A. "High-calcium fly ash as the fourth constituent in concrete: problems, solutions and perspectives", Cement and Concrete Composites, 27(2), pp. 231-237, 2005. https://doi.org/10.1016/j.cemconcomp.2004.02.012

[7] Yao, Z. T., Ji, X. S., Sarker, P. K., Tang, J. H., Ge, L. Q., Xia, M. S., Xi, Y. Q. "A comprehensive review on the application of coal fly ash", Earth-Science Reviews, 141, pp. 105-121, 2015.

https://doi.org/10.1016/j.earscirev.2014.11.016

[8] Karayannis, V. G., Karapanagioti, H. K., Domopoulou, A. E., Komilis, D. P. "Stabilization/Solidification of Hazardous Metals from Solid Wastes into Ceramics", Waste and Biomass Valorization, 8(5), pp. 1863-1874, 2017. https://doi.org/10.1007/s12649-016-9713-z 
[9] Pergal, M. M., Relić, D., Tešić, Ž. L., Popović, A. R. "Leaching of polycyclic aromatic hydrocarbons from power plant lignite ash-influence of parameters important for environmental pollution", Environmental Science and Pollution Research, 21(5), pp. 3435-3442, 2014.

https://doi.org/10.1007/s11356-013-2314-5

[10] Tsiridis, V., Petala, M., Samaras, P., Kungolos, A., Sakellaropoulos, G. P. "Environmental hazard assessment of coal fly ashes using leaching and ecotoxicity tests", Ecotoxicology and Environmental Safety, 84, pp. 212-220, 2012. https://doi.org/10.1016/j.ecoenv.2012.07.011

[11] Karayannis, V. G., Moustakas, K. G., Baklavaridis, A. N., Domopoulou, A. E. "Sustainable Ash-Based Geopolymers", Chemical Engineering Transactions, 63, pp. 505-510, 2018. https://doi.org/10.3303/CET1863085

[12] Xu, G., Shi, X. "Characteristics and applications of fly ash as a sustainable construction material: A state-of-the-art review", Resources, Conservation and Recycling, 136, pp. 95-109, 2018. https://doi.org/10.1016/j.resconrec.2018.04.010

[13] Belviso, C. "State-of-the-art applications of fly ash from coal and biomass: A focus on zeolite synthesis processes and issues", Progress in Energy and Combustion Science, 65, pp. 109-135, 2018.

https://doi.org/10.1016/j.pecs.2017.10.004

[14] Kioupis, D., Kavakakis, C., Tsivilis, S., Kakali, G. "Synthesis and Characterization of Porous Fly Ash-Based Geopolymers Using Si as Foaming Agent", Advances in Materials Science and Engineering, 2018, Article ID: 1942898, 2018. https://doi.org/10.1155/2018/1942898

[15] Karayannis, V., Moutsatsou, A., Domopoulou, A., Katsika, E., Drossou, C., Baklavaridis, A. "Fired ceramics $100 \%$ from lignite fly ash and waste glass cullet mixtures", Journal of Building Engineering, 14, pp. 1-6, 2017. https://doi.org/10.1016/j.jobe.2017.09.006

[16] Zhuang, X. Y., Chen, L., Komarneni, S., Zhou, C. H., Tong, D. S., Yang, H. M., Yu, W. H., Wang, H. "Fly ash-based geopolymer: clean production, properties and applications", Journal of Cleaner Production, 125, pp. 253-267, 2016. https://doi.org/10.1016/j.jclepro.2016.03.019

[17] Adell, V., Cheeseman, C. R., Doel, A., Beattie, A., Boccaccini, A. R. "Comparison of rapid and slow sintered pulverised fuel ash", Fuel, 87(2), pp. 187-195, 2008. https://doi.org/10.1016/j.fuel.2007.04.009

[18] Karamberi, A., Moutsatsou, A. "Vitrification of lignite fly ash and metal slags for the production of glass and glass ceramics", China Particuology, 4(5), pp. 250-253, 2006. https://doi.org/10.1016/S1672-2515(07)60269-3

[19] Moutsatsou, A., Protonotarios, V. "Remediation of polluted soils by utilizing hydrothermally treated calcareous fly ashes", China Particuology, 4(2), pp. 65-69, 2006. https://doi.org/10.1016/S1672-2515(07)60236-X

[20] Papandreou, A., Stournaras, C. J., Panias, D. "Copper and cadmium adsorption on pellets made from fired coal fly ash", Journal of Hazardous Materials, 148(3), pp. 538-547, 2007. https://doi.org/10.1016/j.jhazmat.2007.03.020
[21] Dindi, A., Quang, D. V., Vega, L. F., Nashef, E., Abu-Zahra, M. R. M. "Applications of fly ash for $\mathrm{CO}_{2}$ capture, utilization, and storage", Journal of $\mathrm{CO}_{2}$ Utilization, 29, pp. 82-102, 2019. https://doi.org/10.1016/j.jcou.2018.11.011

[22] Wang, S. "Application of Solid Ash Based Catalysts in Heterogenous Catalysis", Environmental Science and Technology, 42(19), pp. 7055-7063, 2008. https://doi.org/10.1021/es801312m

[23] Wang, Y., He, Y., Lai, Q., Fan, M. "Review of the progress in preparing nano $\mathrm{TiO}_{2}$ : An important environmental engineering material", Journal of Environmental Sciences, 26(11), pp. 2139-2177, 2014. https://doi.org/10.1016/j.jes.2014.09.023

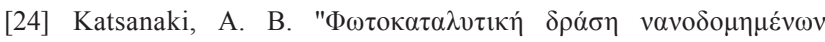

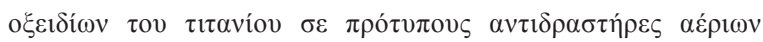
$\tilde{\pi} \pi \omega v^{\prime \prime}$ (Photocatalytic activity of nanostructured titanium oxide materials in standardized reactors of air pollutants)", $\mathrm{PhD}$ thesis, National Technical University of Athens, 2012. (in Greek)

[25] Lei, X. F., Xue, X. X. "Preparation, characterization and photocatalytic activity of sulfuric acid-modified titanium-bearing blast furnace slag", Transactions of Nonferrous Metals Society of China, 20(12), pp. 2294-2298, 2010. https://doi.org/10.1016/S1003-6326(10)60643-7

[26] Adam, F., Appaturi, J. N., Thankappan, R., Nawi, M. A. M. "Silica-tin nanotubes prepared from rice husk ash by sol-gel method: Characterization and its photocatalytic activity", Applied Surface Science, 257(3), pp. 811-816, 2010. https://doi.org/10.1016/j.apsusc.2010.07.070

[27] Gilja, V., Katančić, Z., Krehula, L. K., Mandić, V., Hrnjak-Murgić, Z. "Efficiency of $\mathrm{TiO}_{2}$ catalyst supported by modified waste fly ash during photodegradation of RR45 dye", Science and Engineering of Composite Materials, 26(1), pp. 292-300, 2019. https://doi.org/10.1515/secm-2019-0017

[28] Shi, J. W., Chen, S. H., Wang, S. M., Wu, P., Xu, G. H. "Favorable recycling photocatalyst $\mathrm{TiO}_{2} / \mathrm{CFA}$ : Effects of loading method on the structural property and photocatalytic activity", Journal of Molecular Catalysis A: Chemical, 303(1-2), pp. 141-147, 2009. https://doi.org/10.1016/j.molcata.2009.01.016

[29] Frontistis, Z., Hapeshi, E., Fatta-Kassinos, D., Mantzavinos, D. "Ultraviolet-activated persulfate oxidation of methyl orange: A comparison between artificial neural networks and factorial design for process modelling", Photochemical \& Photobiological Sciences, 14(3), pp. 528-535, 2015. https://doi.org/10.1039/C4PP00277F

[30] Vlyssides, A. G., Papaioannou, D., Loizidoy, M., Karlis, P. K., Zorpas, A. A. "Testing an electrochemical method for treatment of textile dye wastewater", Waste Management, 20(7), pp. 569-574, 2000. https://doi.org/10.1016/S0956-053X(00)00028-3

[31] Spurr, R. A., Myers, H. "Quantitative Analysis of Anatase-Rutile Mixtures with an X-Ray Diffractometer", Analytical Chemistry, 29(5), pp. 760-762, 1957. https://doi.org/10.1021/ac60125a006

[32] Yetim, T., Tekin, T. "A Kinetic Study on Photocatalytic and Sonophotocatalytic Degradation of Textile Dyes", Periodica Polytechnica Chemical Engineering, 61(2), pp. 102-108, 2017. https://doi.org/10.3311/PPch.8535 